\title{
Specific utilization methods of high-melting wastes from the enterprises of chemistry and non-ferrous metallurgy
}

\author{
Aleksey Khlystov ${ }^{1, *}$, Vladimir Shirokov ${ }^{1}$, and Elena Vlasova ${ }^{1}$ \\ ${ }^{1}$ Samara State Technical University, Academy of Civil Engineering and Architecture, \\ Molodogvardeyskaya St., 194, Samara, 443001, Russia
}

\begin{abstract}
The article provides information on industrial waste generation at enterprises of the Samara region, suitable for use as raw materials components of such heat-resistant composites as solutions, concretes, gun mixes, coatings. The research indicates rational ways of some heatresistant binders application for utilization of mineral high-melting and heat-resistant industrial wastes. It proves that the enrichment of certain types of industrial waste, i.e. bringing the chemical composition of their components to the required state, allowed to expand the raw material base for the synthesis of heat-resistant binders and concrete in general. The use of sludge waste in the processes of synthesizing liquid phosphate binders allowed to obtain such effective binders as aluminophosphates and aluminocalciumphosphates. The research proves that application of technogenic wastes of non-ferrous metallurgy enterprises allows to receive heat-resistant materials solutions, concretes, coatings, gun mixes which characteristics are similar to their industrial analogues.
\end{abstract}

\section{Introduction}

On the territory of Samara region, not a dozen of quarries for nonmetallic raw materials extraction (limestone, dolomite, gypsum stone, clay raw materials, sand and gravel mixture and others) are functioning.

In the region, oil and gas production is highly developed to provide local industry and energy complex with fuel. As there is a great number of local raw material available in Samara region, machine building, chemistry and petrochemistry, construction and construction materials industry, non-ferrous metallurgy and other branches of industry have greatly developed. Most enterprises of these industries are sources of waste. [1-3].

A lot of waste can be attributed to technogenic formations, processing of which in some cases allows to solve environmental problems simultaneously, to increase the volume of secondary resources and to solve unemployment problems.

One of the important problems is the production of materials with high physico-thermal properties for linings of thermal generating units operating in complex physico-chemical

\footnotetext{
*Corresponding author: alex-x1950@yandex.ru
} 
conditions (high temperature, aggressive gas environment, direct contact of lining material with metal and alloy melts, fluxes, slags and scale melts At the building materials enterprises represented by sintering plants and brickworks, waste is formed in the form of claydite dust and ceramic scrap brick. Such fired products are quite suitable as fine additives and heat-resistant concrete heat-resistant aggregates.

\section{Materials and methods}

The dead catalyst IM-2201 is formed at Novokuibyshevsk oil refinery when producing styrene-butadiene rubber, as well as at Togliatti synthetic rubber plant. The finely dispersed catalyst, which is a mixture of powdered metals (aluminum and chromium), is oxidized as a result of chemical processes and converted to a finely dispersed mixture of crystalline oxides $\mathrm{Al}_{2} \mathrm{O}_{3}+\mathrm{Cr}_{2} \mathrm{O}_{3}$ (alumina-chromium waste).

The content of $\mathrm{Al}_{2} \mathrm{O}_{3}$, presented in the form of corundum, is $72-75 \%$, and chromium oxide $\mathrm{Cr}_{2} \mathrm{O}_{3}$ is $13-15 \%$. These oxides have very high melting points $\left(1900-2050^{\circ} \mathrm{C}\right.$.). The spent catalyst itself has heat resistance of more than $2000^{\circ} \mathrm{C}$. Therefore, the most promising direction is the use of finely dispersed aluminochromic waste (spent catalyst IM-2201) as finely dispersed heat resistant additive in the compositions of heat-resistant concrete on Portland cement, on liquid glass, using silicate-clods (semi finished product of liquid glass), on phosphate binders. The spent catalyst IM-2201 in the compositions of heat-resistant concrete can also be used directly in the lining of its own thermal generating units.

Pyritic cinders are formed in sulfuric acid plants. At Chapayevsk Chemical Plant many tons of loose ferrous waste accumulated when sulfuric acid production was functioning. Perhaps, these wastes are on special polygons. Pyritic cinders are formed by $\mathrm{FeS}_{2}$ pyrite burning to produce sulfuric anhydride $\mathrm{SO}_{2}$. That is why, in the chemical composition of pyritic cinders, iron-containing compounds predominate in the form of oxides $\mathrm{Fe}_{2} \mathrm{O}_{3}, \mathrm{FeO}$ and hydroxides $\mathrm{Fe}(\mathrm{OH})_{3}$ and $\mathrm{Fe}(\mathrm{OH})_{2}$. Their total content does not exceed $70-75 \%$. So, the most promising direction is their use in the form of finely ground heat-resistant additive in the processes of synthesizing air-hardening heat-resistant phosphate binders.

Phosphorous slag is a type of waste generated in the production of orthophosphoric acid in Togliatti at the Kuibyshevphosphor plant. During this enterprise operation, millions of tons of phosphorus slag accumulated on landfills, that forms in the process of roasting $\mathrm{t} \geq$ $1500^{\circ} \mathrm{C}$ of phosphorus-containing ores (apatites and phosphorites) in ore-thermal furnaces in order to extract elemental phosphorus. The chemical composition of phosphorus slag is represented by the following oxides in \% silicon: 40-43, calcium 42-46; aluminum - 3 - 4; magnesium - 2 - 3; iron - 0 - 1; alkali metals - 0.8 - 1.3; phosphorus - 2,5 - 3,0. Moreover, the presence of sulfuric anhydride and fluorine compounds in the amount of $0.5-2 \%$ is possible in phosphorus slag. The mineralogical composition of phosphorus slag is represented by single-calcium silicate $\mathrm{CaO} \mathrm{SiO}_{2}$ in the form of awollaetonite mineral. Waste heat resistance is $1380-1400{ }^{\circ} \mathrm{C}$, and it makes it possible to use very strong phosphoric slag as heat-resistant concrete aggregate practically on all types of binders. A mineralogical composition of phosphorus slag suggests that it can be used in a finely dispersed state as a chemical curing agent for heat-resistant binders on liquid glass [4-7].

Dump salt slags from aluminum alloys melting are waste of non-ferrous metallurgy. Salt slags (Samara Metallurgical Plant) are formed during remelting of secondary aluminum alloys in reverberatory furnaces with the addition of up to $30 \%$ fluxes. Slags contain a large amount of alumina, and a greater amount of salts (mainly potassium and sodium chlorides). Slags salinity is a serious obstacle for their processing into a useful product.

The cooled slag is subjected to crushing and grinding and it is dispersed into fractions. Waste requiring recycling is a fraction with a grain size of less than $0.14 \mathrm{~mm}$. Even in this 
fraction there are metallic grains of aluminum. In this connection, a technology for the enrichment of this slag has been developed, and this technology facilitates its transfer to a useful product, in particular, to technical alumina $\gamma-\mathrm{Al}_{2} \mathrm{O}_{3}$, which is a very valuable product, in particular, a fine-milled heat-resistant additive of heat-resistant phosphate hardening concrete. Also, pasty waste in the form of sludge are formed at Samara Metallurgical Plant.

Alkaline aluminum etching sludge or alumino alkali sludge is formed as a result of alloys treatment with a concentrated solution of $\mathrm{NaOH}$ alkali. In the process of neutralizing the alumino alkali sludge with carbonate compounds, alumino-calcium sludge is formed. As a result of separate mixing of alumino-alkali and alumino-calcium sludge with orthophosphoric acid, an exothermic reaction occurs between the mineral constituents of nanotechnogenic waste with $\mathrm{H}_{2} \mathrm{PO}_{4}$. Taking into account the chemical composition of sludge, it is possible to assume that the liquid phosphate binders based on the aluminoalkali sludge will consist of water-soluble aluminophosphates such as $\mathrm{Al}\left(\mathrm{H}_{2} \mathrm{PO}_{4}\right)_{3}$ and $\mathrm{Al}_{2}$ $\left(\mathrm{HPO}_{4}\right)_{3}$ and based on alumino-calcium sludge - from compounds such as $\mathrm{Ca}\left(\mathrm{H}_{2} \mathrm{PO}_{4}\right)_{2}, \mathrm{Mg}$ $\left(\mathrm{H}_{2} \mathrm{PO}_{4}\right)_{2}$ and $\mathrm{Al}\left(\mathrm{H}_{2} \mathrm{PO}_{4}\right)_{3}$ possibly.

The above-mentioned acidic water-soluble phosphate binders proved to be very reactively active components in the compositions of non-fireproof heat-resistant solutions and concretes, ramming masses [8-9].

Nanotechnogenic raw materials in the form of alumino-calcium sludge proved to be a very versatile fine-milled additive in the composition of mopled small-piece refractory products. Two-component batch consisting of sludge and spent refractory scrap in the form of chamotte sand of $0-5 \mathrm{~mm}$ fraction was closed with ortho-phosphoric acid of a certain concentration or solution of aluminocalciumphosphate binder of $1.45-1.5 \mathrm{~g} / \mathrm{cm}^{3}$ density. Samples, i.e. cylinders with a height and diameter of $50 \mathrm{~mm}$, were molded from the obtained mixture using the pressing method under pressure from 50 to $150 \mathrm{~kg} / \mathrm{cm}^{2}$. After a short heat treatment $\left(300-400^{\circ} \mathrm{C}\right)$, the products had physico-thermal parameters comparable with those for standard pieces of chamotte refractories [10].

\section{Experiments and results}

To produce mixed aluminoferrophosphate concrete as alumina-containing component, technical products such as high-alumina: technical alumina, fine-grained corundum, and others, as well as industrial wastes, for example, aluminum chromium spent petrochemical catalyst IM-2201, and calcined salt slag containing up to $95 \% \mathrm{Al}_{2} \mathrm{O}_{3}$ can be used. When the latter component is introduced into the pyritic cinder composition with ortho-phosphoric acid, a mixed astringent having different properties than pure iron phosphate is formed. Heat-resistance of mixed aluminoferrophosphate cement increases almost directly proportional to the amount of alumina-containing product introduced into phosphate composition.

Setting time of the mixed binder is prolonged, but even with $80-90 \%$ introduction of calcined salt slag-waste of non-ferrous metallurgy, the ability of phosphate cement test to adhere in air conditions and gain strength with time is kept.

With the subsequent heat treatment, the strength of cement stone based on mixed binder increases due to the formation of high-temperature aluminophosphates. Some compositions of heat-resistant concrete with the use of calcined salt slag and their physico-thermal properties are given in Table 1. 
Table 1. Physico-thermal parameters of phosphate hardening heat-resistant concretes obtained on the basis of calcined salt slag.

\begin{tabular}{|c|c|c|c|c|c|c|c|c|}
\hline \multirow{2}{*}{ No } & \multirow{2}{*}{$\begin{array}{c}\text { Concrete } \\
\text { composition, } \\
\mathbf{k g} / \mathbf{m}^{3}\end{array}$} & \multirow{2}{*}{$\begin{array}{c}\text { Average } \\
\text { density in } \\
\text { dry } \\
\text { condition, } \\
\mathrm{kg} / \mathrm{m}^{3}\end{array}$} & \multicolumn{5}{|c|}{$\begin{array}{c}\text { Compressive strength, MPa after } \\
\text { hardening and heating to } \\
\text { temperature, }{ }^{0} \mathrm{C}\end{array}$} & \multirow{2}{*}{$\begin{array}{c}\text { Thermal } \\
\text { resistance, } \\
\text { water heat } \\
\text { changes }\end{array}$} \\
\hline & & & $\begin{array}{l}20 \\
\text { (days) }\end{array}$ & 500 & 800 & 1200 & 1400 & \\
\hline 1 & $\begin{array}{l}\text { Pyrite cinder-90 } \\
\text { Calcined salt slag- } \\
350 \\
\text { Fire-clay crushed } \\
\text { stone-750 } \\
\text { Fire-clay sand- } \\
650 \mathrm{H}_{3} \mathrm{PO}_{4} \text { (70\% } \\
\text { concentration) } \\
260\end{array}$ & 2010 & 4.5 & 43.1 & 45.3 & 46.2 & 45.1 & 30 \\
\hline 2 & $\begin{array}{l}\text { Pyrite cinders - } 90 \\
\text { Calcined salt slag } \\
-350 \\
\text { High-alumina } \\
\text { crushed stone - } \\
780 \\
\text { High-alumina } \\
\text { sand - } 680 \mathrm{H}_{3} \mathrm{PO}_{4} \\
(70 \% \\
\text { concentration)- } \\
280\end{array}$ & 2100 & 5.9 & 44.6 & 49.2 & 50.5 & 51.5 & 35 \\
\hline
\end{tabular}

In order to expand the field of materials application on liquid phosphate binders, studies were carried out on the development and study of compositions of heat-resistant solutions on their basis, intended both for piece refractories laying and for repair work in the form of coatings on lining.

To protect the metal surfaces of tunnel kilns sides, the composition of heat-resistant heat-insulating solution on expanded clay dust and expanded clay industry waste was developed.

The samples of solutions were tested for compressive strength after heating, for determining the deformation temperature under load and thermal stability. Compositions and some properties of solutions are given in Table 2 .

Table 2. Basic physical and mechanical properties of heat-resistant mortar solutions.

\begin{tabular}{|c|c|c|c|c|c|c|c|}
\hline \multirow{2}{*}{ No } & \multirow{2}{*}{$\begin{array}{l}\text { Solutions composition, } \mathrm{kg} \\
\qquad / \mathrm{m}^{3}\end{array}$} & \multirow{2}{*}{$\begin{array}{c}\text { Average } \\
\text { density of } \\
\text { the } \\
\text { mixture, } \\
\mathrm{kg} / \mathrm{m}^{3}\end{array}$} & \multicolumn{5}{|c|}{$\begin{array}{l}\text { Compressive strength, MPa samples } \\
\text { depending on the heating temperature, }{ }^{0} \mathrm{C}\end{array}$} \\
\hline & & & $\begin{array}{c}20 \\
7 \text { days }\end{array}$ & 500 & 800 & 1000 & 1300 \\
\hline 1 & $\begin{array}{l}\text { Calcened salt slag }-465 \\
\text { Fire-clay sand }-1050 \\
\text { Aluminocalciumphosphate } \\
\text { binder }-580\end{array}$ & 2095 & 30.4 & 31.6 & 30.1 & 28.9 & 32.7 \\
\hline 2 & $\begin{array}{l}\text { Aluminochromium waste of } \\
\text { petrochemistry }-250 \\
\text { Calcined salt slag }-250\end{array}$ & 2105 & 33.6 & 34.8 & 33.9 & 32.1 & 35.2 \\
\hline
\end{tabular}




\begin{tabular}{|c|l|c|c|c|c|c|c|}
\hline & $\begin{array}{l}\text { Fire-clay sand - 1030 } \\
\text { Aluminocalciumphosphate } \\
\text { binder-585 }\end{array}$ & 1350 & 6.4 & 6.3 & 6.1 & 5.9 & - \\
\hline $\begin{array}{l}\text { Ealcined salt slag-220 } \\
\text { Expanded clay sand-720 } \\
\text { Aluminocalciumphosphate } \\
\text { binder-410 }\end{array}$ & 135 & & & & \\
\hline
\end{tabular}

Note: in all three formulations the density of the aluminocalciumphosphate binder was $\rho=1.42 \mathrm{~g} / \mathrm{cm}^{3}$.

Absolute values of compressive strength of samples of clay solutions were shown to be sufficient for their use in liners. However, to make a complete conclusion about the solutions suitability and their use as repair compounds, it is necessary to know their binder strength with refractory material. Adhesive qualities of solutions were determined from their adhesion strength with fire-clay refractory material according to the procedure described in [11].

The ultimate strength at detachment of clay solutions on aluminocalciumphosphate binder increases with firing temperature rise. Test results are given in Table 3.

Table 3. Thermal and adhesive properties of mortar solutions.

\begin{tabular}{|c|c|c|c|c|c|c|c|c|c|}
\hline \multirow{2}{*}{$\begin{array}{c}\text { No. of } \\
\text { compositions } \\
\text { according to } \\
\text { Table } 15\end{array}$} & \multicolumn{5}{|c|}{$\begin{array}{c}\text { Adhesion trength of masonry mortar } \\
\text { with chamotte substrate, MPa after } \\
\text { heating at temperature }{ }^{0} \mathrm{C}\end{array}$} & \multicolumn{3}{|c|}{$\begin{array}{c}\text { Deformation } \\
\text { temperature under } \\
\text { load, }{ }^{0} \mathrm{C}\end{array}$} & \multirow{2}{*}{$\begin{array}{c}\text { Thermal } \\
\text { resistance, } \\
\text { water heat } \\
\text { changes }\end{array}$} \\
\hline & $\begin{array}{l}20 \\
7 \text { days }\end{array}$ & 400 & 800 & 1000 & 1300 & H.P. & $4 \%$ & $40 \%$ & \\
\hline 1 & 4.9 & 4.8 & 4.9 & 5.1 & 5.3 & 1180 & 1250 & 1370 & 24 \\
\hline 2 & 4.8 & 4.5 & 5.8 & 5.6 & 5.6 & 1210 & 1300 & 1380 & 26 \\
\hline 3 & 1.5 & 1.7 & 2.0 & 2.1 & - & 1080 & 1190 & 1230 & 20 (air) \\
\hline 4 & 0.15 & 0.4 & 1.1 & 1.6 & 1.6 & - & - & - & 10 \\
\hline
\end{tabular}

Note: 1 . The solution thickness for beams gluing was $2-4 \mathrm{~mm}$.

2. For composition No. 3 adhesion strengths of solution with metal surface are given.

3. Under No. 4 a traditional chamotte-clay solution of the following composition was tested: chamotte sand $-55 \%$, refractory clay $-15 \%$, water $-30 \%$.

\section{Discussion}

According to the adhesion strength, phosphate mortar solutions exceed the chamotte-clay solution even with different gluing thickness. It happens due to the fact that aluminocalciumphosphate binder, when absorbed into the surface layers of fireclay refractory material, changes its phase composition towards convergence with that solution. The thermal expansion coefficients of the solution and refractory material become very close to each other. This circumstance also determines the high adhesion properties of solutions and a much longer lifetime of the liner. For a solution designed to protect metal surfaces of the trolleys sides, additional adhesion properties determination was carried out with C-3 steel.

Thus, the introduction of various finely ground fillers (chamotte, expanded clay dust, calcined salt slag, aluminochromium petrochemistry waste) into the active component (carbonate + liquid phosphate binder) made it possible to obtain heat-resistant aerated concrete with density from 400 to $800 \mathrm{~kg} / \mathrm{m}^{3}$ and strength after hardening and drying ranging from 2,5 to 5,0 $\mathrm{MPa}$. The application temperature of these porous materials due to the formation of high-temperature metal phosphates is $1300-1500^{\circ} \mathrm{C}$, which makes it possible to use them for manufacturing heat-insulating part of industrial furnaces lining instead of expensive and scarce lightweight pieces. 
As to the use of liquid phosphate shutters in the process of making blends for pressing refractory semi-finished products one can expect their chemical interaction not only with the powder part, but also with the surface of grains aggregate considering their high activity. The speed of this chemical interaction is obviously determined by chemical composition, the dispersion of powder part, and the granulometry of the fine aggregate present in blend for compression molding, as well as shutter acidity. In this case, a very thin surface layer is formed on the surface, separating the fine aggregate in mold powder from mold (cement stone) and facilitating stresses removal in the product. This circumstance explains the very high thermal stability of phosphate heat-resistant composites in comparison with firing products of similar composition (aluminosilicate chamotte, highaluminous, mullite and corundum).

\section{Conclusions}

In the present work, an attempt to consider the use of high-melting aggregates in a polyfunctional way when producing molded phosphate-chamotte refractories was made. Aluminocalcium sludge is considered to be such component; i.e. nanotechnogenic raw materials, formed as industrial waste at Samara Metallurgical Plant.

Nanotechnogenic raw materials in the form of aluminocalcium sludge when mixed with orthophosphoric acid of a certain concentration allowed to obtain acidic water-soluble aluminocalciumphosphate binder $(\mathrm{ACPhB})$. This binder is quite suitable to be used as a grounding fluid of various heat-resistant solutions and concretes.

The first experiments on the preparation of compacted phosphate refractories were successful. Alumoinocalcium sludge was mixed with heat-resistant chamotte scrap of 0-5 $\mathrm{mm}$ fraction, if necessary, heat-resistant clay or calcined salt slag was introduced into the blend. Then the blend was closed with $\mathrm{ACPhB}$ until a semi-dry mass that was suitable in the pressing technology at various pressures to receive semi-finished chamotte products. Further heat treatment $\left(300-400^{\circ} \mathrm{C}\right)$ of freshly pressed products increases the physical and thermal parameters of chamotte products, making them standard.

Calcined salt slag proved to be quite suitable for the preparation of mixed aluminophosphate cements. Studies have also shown that its composition is similar to a standard product, i.e. technical alumina. The technology for obtaining calcined salt slag is quite simple, it does not require special firing equipment. For its production existing burning equipment such as rotary kilns, fluidized bed furnaces and other similar thermal units is quite suitable.

\section{References}

1. T.B. Arbuzova, V.A. Shabanov, S.F. Korenkova, N.G. Chumachenko, Building materials from industrial wastes (Samara, 1993)

2. Т.Б. Arbuzova, Utilization of clay-containing precipitation of industrial wastes (Saratov University Publishing House, Samara Branch, Samara 1991)

3. Т.Б. Arbuzova, N.G. Chumachenko, Heat-resistant concretes and their structures, Penza, 10 (1988)

4. V.A. Abyzov, A.K. Abramov, V.M. Rytvin, Refractories and technical ceramics 11/12, 43 (2010)

5. A.P. Tarasova, Heat-Resistant Concretes on Liquid Glass, Physicochemical and Technological Foundations of Heat-Resistant Cements and Concretes (Nauka, Moscow, 1986) 
6. A.P. Tarasova, Heat-resistant binders on liquid glass and concretes based on them (Stroyizdat, Moscow, 1982)

7. K.D. Nekrasov, A.P. Tarasova, Concrete and reinforced concrete 11, 14 (1977)

8. A.I. Khlystov, S.V. Sokolova, M.V. Konnov, Refractories and technical ceramics 11, 35 (2012)

9. B.Y. Trofimov, V.A. Abyzov, Actual Problems of Building Materials Science, TGASU - Tomsk, 96 (1998)

10. V.A. Perepelitsyn, V.A. Koroteev, et al, Refractories and technical ceramics 6, 42 (2011)

11. A.I. Khlystov, S.V. Sokolova, Refractories and technical ceramics 5, 41 (2007) 